\title{
Azərbaycanda məktəbli uşaq və yeniyetmələr arasında reproduktiv sağlamlığa dair aparılan
} sorğunun nəticələri

C.Məmmədov1, S.Babazadə1, M.Qaraxanova2, E.Zeynalova2, İ.İsrafilbəyova2, N.Feyzullayeva2

1Səhiyyə Nazirliyinin İctimai Səhiyyə və İslahatlar Mərkəzi

2Azərbaycan Dövlət Həkimləri Təkmilləșdirmə İstitutu

Açar sözlər: reproduktiv sağlamlıq, yeniyetmələr, cinsi yetişkənlik, dispanserizasiya, məktəblilər

Maliyyə mənbəyi: məqalənin hazırlanması üçün digər qurumlardan və ya şəxslərdən əlavə maliyyə vəsaiti cəlb edilməmişdir.

Maraqların toqqușması: yoxdur

Müəlliflərin töhfəsi. Đəəbiyyatın icmalı, biblioqrafiyanın təhlil üçün seçilməsi: S.Babazadə. Məqalənin yazılması: C.Məmmədov, S.Babazadə, M.Qaraxanova, E.Zeynalova,

İ.İsrafilbəyova, N.Feyzullayeva

Çapa qəbul edilib: fevral 2018

\begin{abstract}
Abstrakt.
"Uşaqların icbari dispanserizasiyadan keçirilməsinə dair Dövlət Proqramı” nın icrası ilə bağlı Azərbaycan Respublikasının Səhiyyə Nazirliyinin Tədbirlər Planının müvafiq bəndinə əsasən aparılmış tədqiqatın əsas vəzifəsi Bakı şəhərinin nümunəsində ölkənin tam orta məktəblərində təhsil alan orta və yuxarı sinif şagirlərinin icbari dispanserizasiyadan keçirilməsini qiymətləndirmək, dispanserizasiya prosesi zamanı təhsil müəssisələri, tibb müəssisələri, uşaqlar və valideynlərin qarşılaşdıqları hər hansı çətinlik və problemləri müəyyən etmək olub.
\end{abstract}

\section{Tədqiqatın məqsədi:}

Uşaqların sağlamlıq durumu, habelə uşaqların və valideynlərin reproduktiv sağlamlığa dair məlumatlılıq səviyyəsini və xəstəliklərlə bağl1 həkimə müraciətləri, eləcə də pediatrların məktəbyaşlı uşaq və yeniyetmələrə reproduktiv sağlamlıqla bağlı müayinələrin aparılmasının, bu mövzularla bağlı müəllimlərin şagirdlərə biliklərin çatdırılmasını müəyyən etməkdir.

\section{Tədqiqatın material və metodları.}

Tədqiqatın aparılması üçün xüsusi sorğu vərəqələri Səhiyyə Nazirliyinin İctimai Səhiyyə və İslahatlar Mərkəzi (İSIM), Elmi-təədqiqat Pediatriya İnstitutu (ETPI) və Bakı şəhər Səhiyyə İdarəsinin mütəxəssislərinin iştirakı ilə hazırlanmışdır. Sorğu 2014-cü ildə Bak1 şəhərində 996 nəfər 10-18 yaşlı (tam orta məktəblərin 6-10-cu sinif şagirdləri) uşaq və yeniyetmələr arasında aparılmışdır. Sorğu suallarının böyük əksəriyyəti uşaqların icbari dispanserizasiyadan və dispanserizasiyadan kənar həkim müayinələrinə cəlb edilməsi, dispanserizasiya zamanı qarşıya çıxmış çətinlik və problemlərin öyrənilməsini, habelə uşaq və yeniyetmələrin sağlam həyat tərzi və zərərli vərdişlər, reproduktiv sağlamlıq məsələlərini əhatə etmişdir.

Sorğuda iştirak edən 996 uşaqdan 15-17 yaş kateqoriyasında olanların sayı 264 nəfər və ya 26.5\%, 10-11 yaş kateqoriyasında - 152 uşaq və ya $15.3 \%$ və $12-14$ yaş kateqoriyasında olanların sayı isə 580 uşaq vo ya $58.3 \%$ olmuşdur. Uşaqlar arasında oğlan və qızların sayı təxminən eyni olmuşdur. Oğlanların sayı 502, qızların isə 494 idi.

\section{Alınmış nəticələrin müzakirəsi.}

Son 12 ay ərzində həkimin qəbuluna düşmək 
üçün hans1 müəssisələrə müraciət etdiklərinə dair verilən suala uşaqların 449 nəfəri (45\%) müayinə üçün ərazi üzrə sahə poliklinikasına, 31nəfəri (3.1\%) məktəbə yaxın poliklinikaya, 40 nəfəri (4\%) məktəb tibb məntəqəsinə müraciət etdiklərini vurğulamışlar.

Uşaqlardan son 12 ay ərzində həkimin qəbulunda olub-olmadıqlarını soruşduqda, uşaqların 324 nəfəri $(32.5 \%)$ ötən 12 ay ərzində 1 dəfə, 335 nəfəri (33.6\%) 2-3 dəfə və 96 nəfəri (9.6\%) 3 dəfədən çox həkimin qəbulunda olduqlarını bildiriblər. Uşaqların 221 nəfəri (22.2\%) ötən 12 ay ərzində ümumiyyətlə, həkimin qəbulunda olmamış, uşaqlar arasında həkimə müraciət etməyərək vaxtında diaqnozun qoyulmaması isə onları çox bahalı və uzunmüddətli müalicəyə sövq etmiş, eləcə də orqanizmin funksiyasının bərpas1 və uşağın, bütövlükdə isə ailənin psixoloji reabilitasiya olunması fikrinə gətirir.

Son 12 ayda hansı həkim tərəfindən müayinə olunduqlarına dair verilmiş suala 756 uşaqdan 466 nəfəri $(61.6 \%)$ pediatr, 49 nəfəri $(6.5 \%)$ yeniyetmə həkimi, 328 nəfəri (43.4\%) LOR, 295 nəfəri (39\%) nevropatoloq və 256 nəfəri (33.9\%) kardioloqa müraciət edərək müayinə olunmuşlar. Sorğuların təhlili göstərdi ki, uşaq cərrahı tərəfindən uşaqların müayinəsi cəmi $23 \%$ hallarda baş vermişdir.

Məlumdur ki, uşaqlar böyüyür, onların maraq dairəsi də genişlənir, sağlam həyat tərzinin tərbiyyə olunması da məs. elə məktəb illərində formalaşaraq inkişaf etdirilir. $\mathrm{Bu}$ baxımdan, aparılan sorğularda uşaq və yeniyetmələr arasında ümumiyyətlə, çox həssas məsələ olan zərərli vərdişlər, reproduktiv sağlamlıqla bağlı suallara xüsusi olaraq yer ayrılmışdır.

Reproduktiv sağlamlıq və yetişkənlik mövzusu həssas olan mövzulardandır. Xüsusilə də uşaq və yeniyetmələr arasında. Milli və dini ənənələrə, siyasi quruluşa və digər şərtlərə görə üstünlüyündən asılı olaraq müxtəlif ölkələr bu və ya digər modeli qəbul edirlər. Yeniyetmələrin reproduktiv sağlamlıq probleminin əksər tədqiqatçıları inanırlar ki, yeniyetmələrin seksual tərbiyəsində tibb işçilərini aparıcı rol oynamalıdırlar və ilk növbədə bu, uşaqlarla təmasda olan sahə pediatrlarına aiddir. Ancaq bəzi tədqiqatlar göstərir ki, sahə pediatrlarının yalnız yarısı cinsi tərbiyəni əhəmiyyətli vəzifələrdən biri hesab edir və 11 ilədək təcrübəsi olan həkimlər arasında bu göstərici daha aşağıdır, bəziləri isə seksual maarifləndirmə üçün onların məsuliyyət daşımadıqlarına inanırlar. Həqiqətdə isə anketin nəticələrinə görə sorğu edilən həkimlərin yarıdan az hissəsi uşaqlarla və onların valideynləri ilə cinsi tərbiyədə fərdi söhbət formasında iştirak edirlər. Ancaq tədqiqatçılar bu göstəriciləri çox yüksək hesab edir və qeyd edirlər ki, nə uşaqlarla, nə də məktəbdəki müəllimlərlə, sahə pediatrları praktik olaraq işləmirlər [11, c. 11].

Azərbaycanda oğlan və qizlar arasında ginekoloq ya androloji skrininq müayinələrindən keçməsi təcrübəsi demək olar ki, həyata keçirilmir. Reproduktiv sağlamlığa dair narahat edən məsələlərin aradan qaldırması ancaq xəstəliklər və ya nasasızlıq baş verdikdə həkimə müracıət etməklə olunur. Mövzularla bağlı maariflənmə prosesi isə nədənsə, Azərbaycanda uşaq və yeniyetmələrə bu mövzulara dair məlumatlar tam şəkildə çatdırılmır. Yeniyetmənin bu sahədə olan marağı da təbiidir. Amma ilk molumat, təcrübəni o hardan əldə edir? Bununla bağl1, aparılan sorğuların təhlili göstərdi ki, cinsi yetişkənlik və ümumiyyətlə, reproduktiv sağlamlıq barədə məlumatı əldə etmək məqsədilə uşaqların böyük bir hissəsi (42.6\%) ilk dəfə üzünü internetə tutur. Uşaqların yalnız 15.9\%-i bu məsələlərə dair ilk məlumatı valideyn, 15.9\%-i 
isə yaxın qohum və dostlar tərəfindən aldıqlarını qeyd etmişlər.

Ölkədə həkimlərin təkmilləşdirmə kurslarına cəlb olunan 80 nəfər həkim-pediatrların reproduktiv sağlamlıq, cinsi tərbiyyə ilə bağlı məktəblilərə məlumatların kim tərəfindən çatdırılması məsələsinə yanaşması eyni olmamışdır. Belə ki, həkimlərin $75 \%$ bunu valideynlər tərəfindən çatdırılmasını qeyd etmişlər. Müəllimlərin rolunu bu məsələdə $10 \%$ həkimlər qeyd etmişlər.

Təəssüf ki, tibbi peşə təliminin spesifikliyi bir insanın bioloji yönümlü bir görünüşünü nəzərdə tutur, həkimlərin tibbi bilikləri isə normanın və patologiyanın sadə bir ifadəsinə əsaslanır. $\mathrm{Bu}$, yeniyetmələr və gənclərin cinsi maariflənməsi üzro tam hüquqlu iş aparmaq üçün kifayət deyil, çünki insan münasibətləri daha zəngin və müxtəlifdir.

Ailənin sosial-mədəni böhranı şəraitində tibb işçiləri sağlam həyat tərzinin təbliğatında və riskli cinsi davranışın qarşısının alınmasında əhəmiyyətli rol oynaya bilərlər, çünki mütəxəssis kimi, xəstə ilə əlaqə qurmaq kimi prosesdə gender münasibətlərində onun mövqeyinə təsir göstərə bilər.

Cinsi əlaqə təcrübəsinə gəlincə isə uşaqların 16 nəfəri (8.2\%) bunu etiraf etmişdir. İlk cinsi əlaqə zamanı uşağın yaşı da öyrənilmişdir. Maraqlıdır ki, bu suala cavab vermiş 12 uşaqdan dördü (33.3\%) 15 yaşında, 2 nəfəri (16.7\%) 14 yaşında, 2 nəfəri (16.7\%) 16 yaşında, 2 nəfəri $(16.7 \%)$ isə 12 yaşında ilk dəfə cinsi əlaqənin olmasını qeyd etmişlər. Məktəbdə cinsi yetişkənlik və reproduktiv sağlamlığa dair dərslərin keçirilməsi ilə bağlı verilmiş suala uşaqların 101 nəfəri (10.1\%) dərslərin keçirildiyini bildirmişdir.

Reproduktiv sağlamlıq və cinsi yetişkənlik barədə sual olduqda uşaqların 61 nəfəri $(6,1 \%)$ həkimlərdən müvafiq məsləhətlərin almasını qeyd etmişlər. Bununla yanaşı, qeyd olunmalıdır ki, həkimə müraciətlərin cəmi 4\%-i reproduktiv sağlamlığa dair problemlərlə bağlı olmuşdur. $\mathrm{Bu}$ da ölkədə ümumiyyətlə, reproduktiv sağlamlıqla bağl1, eləcə də cinsiyyət üzvlərində (tez-tez) rast gəlinən dəyişikliklər, xəstəliklər barədə danışmamaq davranış təcrübəsi müşahidəsi, çox vaxt uşaqların utancaqlıq hissləri və bununla da valideynə vaxtında deməməsi ilə də izah edilə bilər.

\section{Ümumi nəticələr və tövsiyyələr.}

Beləliklə, tədqiqatdan alınan nəticələr göstərdi ki, reproduktiv sağlamlıqla bağlı həkimə müraciətlər az olur. $\mathrm{Bu}$ ya uşaqların utancaqlığı ya da valideynlərin məlumatsızlığı ilə əlaqələndirilə bilər. Bununla yanaşı, uşaq və yeniyetmələr üçün təhsil proqramlarında reproduktiv sağlamlıq və cinsi tərbiyyə mövzulara dair məlumatlara yer ayrılmalı və müvafiq üsullar istifadə edərək, təqdim olunmalıdır. $\mathrm{Bu}$ baxımdan uşaqların sağlamlığının mühafizəsi ilə bağlı hər hansı profilaktik və ya müalicəvi tədbirlərin həyata keçirilməsindən öncə geniş əhalinin, xüsusilə də, valideynlərin əvvəlcədən məlumatlandırılması əhəmiyyət kəsb edir.

Nəticə, icbarı dispanserizasiya uşaqların sağlamlığınının mühafizəsi məqsədilə dispanserizasiya proqramı çərçivəsində profilaktik müayinələrə cəlb olunmasına dair ohali arasında molumatlandirma kampaniyalarının, məktəblərdə uşaq və yeniyetmələrin maarifləndirilməsi üçün keçirilən tədbirlərin effektivliyini dəyərləndirməyə imkan verir və mütamadi olaraq aparılmalıdır. $\mathrm{Bu}$ prosesdə pediatrların təkmilləşdirilməsi və valideynlərin məlumatlandırılması, fəal iştirakı zəruridir.

Beləliklə, yeniyetmələrin cinsi tərbiyəsi və seksual təhsillə bağlı problemi çoxfunksiyallıdır və problemləri kompleks şəkildə həll olunmalı, 
müxtəlif növ tibbi mütəxəssislərin, müəllimlərin və valideynlərin iștirakı ilə bir çox məsələlər həll edilməlidir. Eyni zamanda, həm yetkin kişilər, həm də qadınların, o cümlədən də anaların reproduktiv təhsil səviyyəsinin qeyri-adekvat səviyyədə olması, məlumat və təhsil işlərinin ilk növbədə gənc kişilər və qızlar üçün deyil, həm də valideynlər, yeniyetmələri yetişdirən ailələr, eləcə də yeniyetmələrlə işləyən bütün mütəxəssislər, səhiyyə işçiləri də daxil olmaqla, başlıca işləri olmalıdir.

\section{Biblioqrafiya.}

1. Markham WA, Aveyard P, Bisset SL, Lancashire ER, Bridle C, Deakin S. Value-added education and smoking uptake in schools: a cohort study. Addiction. 2008;103:155-161. [PubMed]

2. Tobler AL, Komro KA, Dabroski A, Aveyard P, Markham WA. Preventing the link between SES and high-risk behaviors: "Value-added" education, drug use and delinquency in high-risk, urban schools. Prev Sci. 2011;12(2):211-221. [PMC free article][PubMed]

3. Bonell C, Fletcher A, McCambridge J. Improving school ethos may reduce substance misuse and teenage pregnancy. BMJ. 2007;2007(334):614616. [PMC free article] [PubMed]

4. Markham WA, Young R, Sweeting H, West P, Aveyard P. Does school ethos explain the relationship between value-added education and teenage substance use? A cohort study. Social Science and Medicine. 2012;75:69-76. [PMC free article][PubMed]

5. Noyes J, Lewin S. In: Supplementary Guidance for Inclusion of Qualitative Research in Cochrane Systematic Reviews of Interventions. Version 1 (updated August 2011) Cochrane Collaboration Qualitative Methods Group, Noyes J, Booth A, Hannes K, Harden A, Harris J, Lewin S, Lockwood C, editor. 2011. Extracting qualitative evidence. Available from URLhttp://cqrmg.cochrane.org/supplementalhandbook-guidance.
6. Rees R, Oliver K, Woodman J, Thomas J. Children's views about obesity, body size, shape and weight: a systematic review.London: EPPI Centre, Social Science Research Unit, Institute of Education, University of London; 2009.

7. Noblit G, Hare R. Meta-Ethnography: Synthesizing Qualittive Studies. London: Sage; 1988.

8. Devine J. Can metal detectors replace the panopticon? Cult Anthropol. 1995;10:171-195.

9. Cousins LH. Toward a sociocultural context for understanding violence and disruption in black urban schools and communities. J Soc Welf. 1997;24:41-63.

10. Waldron LM. The messy nature of discipline and zero tolerance policies. Sociological Studies of Children and Youth. 2005;11:81-114.

11. Wilson-Simmons $\mathrm{R}$, Dash $\mathrm{K}$, Tehranifar $\mathrm{P}$, O'Donnell L, Stueve A. What can student bystanders do to prevent school biolence?: Perceptions of students and school staff. J Sch Violence. 2006;5:43-62.

12. Brunson RK, Miller JM. Schools, neighborhoods, and adolescent conflicts: A situational examination of reciprocal dynamics. Justice Quarterly. 2009;26:183-210.

13. Fletcher A, Bonell C, Sorhaindo A, Rhodes T. Cannabis use and 'safe' identities in an inner-city school risk environment. Int J Drug Pol. 2009;20(3):244-250. [PubMed]

14. Astor RA, Meyer HA, Behre WJ. Unowned places and times: Maps and interviews about violence in high schools. Am Educ Res J. 1999;36:3-42.

15. Keddie A. "Some of those girls can be real drama queens": Issues of gender, sexual harassment and schooling. Sex Education. 2009;9:1-16.

16. Astor RA, Meyer HA, Pitner RO. Elementary and middle school students' perceptions of violenceprone school subcontexts. Elem Sch J. 2001;101:511-528.

17. Haselswerdt $M$, Lenhardt A. Reframing school violence: Listening to voices of students. Educational Forum. 2003;67:326-336. 